\title{
Non-Imaging Focusing Technology for the Application in Concentrator Photovoltaic System
}

\author{
Kok-Keong Chong* \\ Faculty of Engineering and Science, Universiti Tunku Abdul Rahman, Off Jalan Genting-Klang, Setapak, Kuala Lumpur, Malaysia
}

There is now global consensus that the new sources of energy have to be renewable and clean to satisfy long term global energy demand without compromising to the issues such as climate change and depletion of fossil fuel. The current dependence on fossil fuels, the need to reduce carbon emissions associated with energy use, and the abundance of sunlight have made solar energy becomes increasingly attractive as alternative source. The current obstacle preventing large scale implementation of solar electricity production is the high price of the photovoltaic (PV) modules due to the expensive semiconductor material and low conversion efficiency. Concentrator photovoltaic (CPV) system is one of the major solutions to lower down the cost of solar electricity. The state-of-the-art CPV cell technology using high efficiency III-V multi-junction semiconductor materials has succeeded to achieve the conversion efficiency of $40 \%$. Though the multi-junction solar cells assembled into CPV module has the average efficiency dropped down to around $30 \%$, it is still almost double the efficiency of flat-plate PV module that normally ranges from $10 \%$ to $17 \%$. Furthermore CPV achieves its best performance at highly concentrated sunlight of about 400-500 suns. Hence, a small piece of CPV module can produce electricity equivalent to 800-1000 times of the power that flat-plate PV module will do. This technology will definitely save a lot of solar electricity cost via replacing the expensive semiconductor material with a low cost reflector or lens. It also indicates that the need of integrating CPV with highly effective solar concentrator will be a new challenge to solar electricity generation in near future.

Solar concentrator plays an important role by making use of optical technology in the design, which can be either reflector or lens to deliver high flux of sunlight onto the CPV module receiver ranging from hundreds to thousand suns. CPV system is one of the most frontier technologies to harness solar energy in which the key players are normally world renown research institutes and high technology Companies such as Fraunhofer Institute for Solar Energy Systems in Germany, Spectrolab subsidiary of Boeing Company, Emcore and Amonix in the United States of America, etc. The disciplines involved in the CPV system is wide and advanced, which includes the knowledge ranging from physics to advanced material science as well as from software, mechanical, electrical to civil engineering. To be more competitive compared with fossil fuel, the current CPV systems using Fresnel lens and Parabolic dish as solar concentrator that are widely deployed in United States, Australia and Europe are facing great challenge to produce uniformly focused sunlight on the solar cells and to reduce the cost of solar concentrator.

Eco-friendly methods in research and development (R\&D) activities are vital for a university to grow and discover new technologies for the betterment of the future generation. Universiti Tunku Abdul Rahman as a budding university is also actively involved in research activities since its humble beginnings ten years ago. Among its many research groups, High Concentration Solar Energy research group, led by K.K. Chong has actively involved in solving various problems faced by the current solar concentrator. The initial idea of this research started off with the discovery of non-imaging focusing technology through many applications in the solar energy such as concentrator photovoltaic (CPV) system (a technology to harness highly concentrated solar energy for direct conversion to electrical power) [1-3], solar furnace system (a technology to harness solar energy for high temperature processes) [4], and solar thermal energy system (a technology to harness solar energy for generating thermal energy or heat) $[5,6]$. The concept of non-imaging optics is not new, but it has not fully explored by the researchers over the world especially in solving the problem of high concentration solar energy, which application is only limited to be a secondary focusing device or low concentration device. With the current advancement in the computer processing power, the research group has successfully invented the non-imaging dish concentrator using numerical simulation method to replace the current parabolic dish as primary focusing device with high solar concentration ratio (more 400 suns) and large collective area (more than $25 \mathrm{~m}^{2}$ ) [7].

Various innovative and creative ideas to minimize the cost of renewable energy in power generation are very important to guarantee a good future of the next generation. We welcome more researchers or industrial players to propose or submit their innovative or creative ideas in reducing the cost of power generation using clean energy source ranging from solar, biomass, wind, geothermal, hydroelectric, ocean wave etc to the Journal of Advances in Robotic and Automation.

\section{Reference}

1. Chong KK, Wong CW, Siaw FL, Yew TK (2010) Optical characterization of nonimaging planar concentrator for the application in concentrator photovoltaic System. J Sol Energy Eng 132.

2. Chong KK, Siaw FL, Wong CW, Wong GS (2009) Design and construction of non-imaging planar concentrator for concentrator photovoltaic system. Renew Energ 34: 1364-1370

3. Chong KK, Wong CW (2009) General formula for on-axis sun tracking system and its application in improving tracking accuracy of solar collector. Solar Energy 83: 298-305

4. Chong KK, Lim CY, Hiew CW (2011) Cost effective solar furnace system using fixed geometry non-imaging focusing heliostat and secondary parabolic concentrator. Renew Energ 36: 1595-1602

5. Chong KK (2010) Optimization of nonimaging focusing heliostat in dynamic correction of astigmatism for a wide range of incidence angles. Opt Lett 35: 1614-1616

6. Chong KK (2010) Optical Analysis for Simplified Astigmatic Correction of NonImaging Focusing Heliostat. Solar Energy 84: 1356-1365

7. Chong KK, Wong CW, Yew TK, Tan MH (2012) Solar Concentrator Assembly Malaysian Patent.

*Corresponding author: Kok-Keong Chong, Faculty of Engineering and Science Universiti Tunku Abdul Rahman, Off Jalan Genting-Klang, Setapak 53300, Kuala Lumpur, Malaysia, E-mail: chongkk@utar.edu.my, kokkeong_c@yahoo.com

Received November 15, 2012; Accepted November 19, 2012; Published November 22, 2012

Citation: Chong KK (2012) Non-Imaging Focusing Technology for the Application in Concentrator Photovoltaic System. Adv Robot Autom 1:e113. doi:10.4172/21689695.1000e111

Copyright: (c) 2012 Chong KK. This is an open-access article distributed unde the terms of the Creative Commons Attribution License, which permits unrestricted use, distribution, and reproduction in any medium, provided the original author and source are credited. 